\title{
Partitioning soil respiration across four age classes of loblolly pine (Pinus taeda L.) on the Virginia Piedmont
}

Kristin M. McElligott ${ }^{* 1}$, John R. Seiler ${ }^{1}$, Brian D. Strahm ${ }^{1}$

${ }^{1}$ Department of Forest Resources \& Environmental Conservation, 228 Cheatham Hall (0324),

Virginia Tech, Blacksburg, VA 24061 United States

*Corresponding author:

Email:kmc2@vt.edu

Tel: $262-388-0279$

(C) 2016. This manuscript version is made available under the Elsevier user license http://www.elsevier.com/open-access/userlicense/1.0/ 


\begin{abstract}
Quantification of the heterotrophic component of total soil respiration is important for estimating forest carbon pools and fluxes, and for understanding carbon dynamics associated with stand development and silvicultural management. We measured the proportion of heterotrophic respiration $\left(\mathrm{R}_{\mathrm{H}}\right)$ to total soil respiration $\left(\mathrm{R}_{\mathrm{S}}\right)$ in extensively managed loblolly pine (Pinus taeda L.) stands of four age classes in the Piedmont physiographic province of Virginia. Our objectives were to evaluate the influence of stand age and seasonality on the proportion of $R_{H}$ to $R_{S}$ $\left(\mathrm{R}_{\mathrm{H}}: \mathrm{R}_{\mathrm{S}}\right) . \mathrm{R}_{\mathrm{H}}$ was partitioned using root exclusion cores, and both $\mathrm{R}_{\mathrm{S}}$ and $\mathrm{R}_{\mathrm{H}}$ were measured 90 days following installation of cores for five seasons. Repeated measures analysis revealed that stand age and measurement season each had a significant effect on $\mathrm{R}_{\mathrm{H}}: \mathrm{R}_{\mathrm{S}}(P<0.001)$, but that there were no interactive effects $(P=0.202)$. Mean $\mathrm{R}_{\mathrm{H}}: \mathrm{R}_{\mathrm{S}}$ during the 12 -month study declined with stand age, and were $0.82,0.73,0.59$, and 0.50 for 3-year-old, 9-year-old, 18- year-old, and 25-year-old stands, respectively. Across all age classes, the winter season had the highest mean $R_{H}: R_{S}$ of 0.85 while summer had the lowest of 0.55 . This study provides estimates of $R_{H}: R_{S}$ in managed loblolly pine systems, and demonstrates the need to consider the impact of stand age and seasonal patterns when estimating net annual carbon $(\mathrm{C})$ budgets of forest ecosystems and to identify the point at which plantations switch from functioning as $\mathrm{C}$ sources to a $\mathrm{C}$ sinks.
\end{abstract}

Keywords: Carbon fluxes; Heterotrophic respiration; Loblolly pine plantations; Soil respiration 


\section{Introduction}

Southeastern planted pine forests play an important role in meeting the increasing demand for forest products (Prestemon and Abt 2002) and in future carbon (C) sequestration strategies (Johnsen et al. 2001, Wear and Greis 2002, Han et al. 2007). Understanding how management, climate, and disturbances influence productivity and $\mathrm{C}$ sequestration in forests requires that mechanistic controls of both above-and below-ground terrestrial $\mathrm{C}$ pools and fluxes are well-understood, and current C stocks can be accurately quantified (Gorte 2009).

The net $\mathrm{C}$ balance of a forest ecosystem is dependent upon $\mathrm{C}$ uptake and storage being greater than $\mathrm{C}$ lost from plant and soil respiration (ecosystem respiration), and other sources [e.g., erosion, fire, harvest, leaching of dissolved organic $\mathrm{C}(\mathrm{DOC})$, methane $\left(\mathrm{CH}_{4}\right)$ emissions] (Lovett et al. 2006, Chapin et al. 2011). Forests influence the transfer of C between the atmosphere and soil as trees fix large amounts of $\mathrm{CO}_{2}$ from the atmosphere through photosynthesis that is then allocated as organic $\mathrm{C}$ both aboveground and belowground. Large amounts of $\mathrm{CO}_{2}$ are returned to the atmosphere through respiration by vegetation and heterotrophic soil organisms. A suite of existing models are commonly used to estimate C fixation and respiration of the trees themselves (e.g., 3-PG, Landsberg and Waring 1997; SECRETS, Sampson et al. 2001, 2008), or to assess the effects of soil C and nutrient cycling on long-term ecosystem C storage (e.g., CENTURY, Parton et al. 1988). However, to analyze and model $\mathrm{C}$ accumulated by the ecosystem, including the $\mathrm{C}$ stored in the soil, the separation of total soil respiration $\left(\mathrm{R}_{\mathrm{S}}\right)$ into components of heterotrophic, microbial respiration $\left(\mathrm{R}_{\mathrm{H}}\right)$ and autotrophic, root respiration $\left(\mathrm{R}_{\mathrm{A}}\right)$ is necessary (Hanson et al. 2000, Subke et al. 2006) 
A measure of net ecosystem production (NEP) represents the potential for organic $\mathrm{C}$ to be stored within or lost from an ecosystem, and helps predict how $\mathrm{C}$ budgets of forest ecosystems will respond to changes in climate, management, or disturbance regimes. Estimates of NEP can be derived by subtracting $\mathrm{R}_{\mathrm{H}}$ from estimates of net primary production (NPP) (Arneth et al. 2010), and used to identify whether a forest functions as a net sink or source of $\mathrm{CO}_{2}$ (Randerson et al. 2002). Considerable effort has been devoted to quantifying fluxes of $\mathrm{CO}_{2}$ from southeastern pine forests of various management intensities and stand ages in an effort to understand the impacts of forest management and stand dynamics on belowground C dynamics, (Gough and Seiler 2004, Wiseman and Seiler 2004, Gough et al. 2005); however, quantifying contributions from $\mathrm{R}_{\mathrm{H}}$ and co-located $\mathrm{R}_{\mathrm{S}}$ to estimate $\mathrm{NEP}$ is challenging and has resulted in large variation in estimates (Singh and Gupta 1977, Hanson et al. 2000, Kuzyakov 2006).

Despite recent efforts in partitioning $\mathrm{R}_{\mathrm{S}}$, there still exists great uncertainty and variability among estimates within forest ecosystems (Hanson et al. 2000, Högberg et al. 2001, Lee et al. 2002, Rey et al. 2002, Lavigne et al. 2003). Previous attempts to partition $\mathrm{R}_{\mathrm{S}}$ suggest the component values in forests range widely, for example, from 5 to $100 \%$ for $R_{H}: R_{S}$, depending on experimental methods, forest type and age, season, and time step of the analysis [e.g., seasonal, annual, or stand rotation length] (Hanson et al. 2000), while the majority of studies show $\mathrm{R}_{\mathrm{A}}$ and $\mathrm{R}_{\mathrm{H}}$ are roughly evenly partitioned between 50 and 60\% (Bond-Lamberty et al. 2004b). However, in southeastern forests, recent attempts to partition $\mathrm{R}_{\mathrm{S}}$ in loblolly pine (Pinus taeda $\mathrm{L}$.) and longleaf pine (Pinus palustris Mill.) stands suggest $\mathrm{R}_{\mathrm{S}}$ is dominated by $\mathrm{R}_{\mathrm{H}}$, with annual $\mathrm{R}_{\mathrm{H}}: \mathrm{R}_{\mathrm{S}}$ estimates from 79 to $96 \%$ (Heim et al. 2015, ArchMiller and Samuelson 2016). Additionally, these studies were conducted in either mid- or late-rotation, intensively managed plantations with considerable competition control. Stand age, land use history, site characteristics, management 
intensity, and seasonality will likely influence $R_{H}: R_{S}$, and variation in $R_{H}: R_{S}$ with stand age and by season has not been reported. It is uncertain if existing annual estimates are applicable to other stands under various management regimes and with differing site characteristics. Uncertainty in the applicability and range of existing estimates that can be used to parametrize ecosystem $\mathrm{C}$ models have important and large impacts on the estimates of $\mathrm{C}$ storage in managed forest ecosystems. A higher proportion of $\mathrm{R}_{\mathrm{H}}$ would result in lower estimates of NEP, whereas a lower proportion of $\mathrm{R}_{\mathrm{H}}$ would result in higher estimates of NEP and ecosystem $\mathrm{C}$ storage.

Various methods have been attempted to partition $\mathrm{R}_{\mathrm{S}}$ and all have a range of indirect and direct effects of disturbance to the soil (Kuzyakov 2006, Subke et al. 2006). Root exclusion techniques that prevent roots from receiving new photosynthate, such as trenching or girdling, are the most widely used method in forest ecosystems for partitioning $R_{S}$ (Epron 2009). Recently, installation of root exclusion cores that function similarly to trenching, as they isolate tree roots from the flow of new photosynthate but minimize disturbance, cost, and time comparatively, have been utilized in partitioning studies to eliminate $\mathrm{R}_{\mathrm{A}}$ and allow for direct measurements of $\mathrm{R}_{\mathrm{H}}$ (Vogel and Valentine 2005, Strahm et al. 2014, Heim et al. 2015, ArchMiller and Samuelson 2016). Core installation severs existing roots, prevents ingrowth of new roots, and over time, non- structural carbohydrate stores in the severed roots are depleted thereby exhausting $\mathrm{R}_{\mathrm{A}}$ inside the core (Heim et al. 2015). Comparing respiration measurements inside the core $\left(R_{H}\right)$ and outside the core $\left(R_{S}\right)$ allow for the necessary partitioning of $R_{S}$ that can be used to more accurately estimate NEP of forest ecosystems.

The objective of this study was to estimate the proportion and seasonality of $R_{H}: R_{S}$ in four age classes (2-3, 7-9, 16-18, and 23-25 year-old stands) of managed loblolly pine (Pinus taeda L.) plantations for one year using root severing cores. We hypothesized that the relative 
value and proportion of $\mathrm{R}_{\mathrm{H}}$ will decrease with increasing stand age and will vary by season. We expected higher proportions of $\mathrm{R}_{\mathrm{H}}: \mathrm{R}_{\mathrm{S}}$ in younger stands to reflect 1 ) higher rates of decomposition of residues from the previous harvest and associated disturbances, and 2) lower root biomass and productivity of young trees. These estimates, in concert with existing estimates of $\mathrm{R}_{\mathrm{H}}: \mathrm{R}_{\mathrm{S}}$ in mid-rotation, intensively managed loblolly pine plantations across the Southeast (Strahm et al. 2014) will ultimately be incorporated into current ecosystem C models to evaluate the effects of management intensity and stand age on NEP in southern pine ecosystems.

\section{Materials and Methods}

\subsection{Study Location}

This study was conducted on the Appomattox-Buckingham State Forest located in the Piedmont physiographic province of VA $\left(37^{\circ} 26^{\prime} 19^{\prime \prime} \mathrm{N}, 78^{\circ} 39^{\prime} 52^{\prime \prime} \mathrm{W}\right)$. The mean elevation of the study area is $185 \mathrm{~m}$, with minimum and maximum elevations of $133 \mathrm{~m}$ and $225 \mathrm{~m}$, respectively. Local topography can be described as gentle rolling slopes and flat terrain. Vegetation is composed of various coniferous (Pinus taeda, Pinus virginiana, Pinus echinata, and Pinus strobus), deciduous (Quercus alba, Quercus coccinea, and Liriodendron tulipifera), and mixed forest stands. Land use-history consists of intensive agricultural use until the 1930's, followed by the establishment of mixed-hardwood forests and pine plantations (VDOF 2010). Average annual precipitation for this region is $109 \mathrm{~cm}$. The average growing season temperature (April through September) is $22.9^{\circ} \mathrm{C}$ and the average winter temperature (December to February) is $3.8^{\circ} \mathrm{C}$ (NCDC.NOAA.gov accessed November 27, 2015). 
The managed loblolly pine stands chosen for this investigation had similar land-use history and had undergone similar management practices since establishment. Stands were evenaged and ranged from 2 to 25 years of age at the beginning of the study. Site preparation prior to planting involved roller drum chopping followed by broadcast burning. All stands were established by hand planting containerized loblolly pine seedlings on $2 \mathrm{~m} \times 3 \mathrm{~m}$ spacing and received herbicide treatment for control of hardwood and herbaceous competition shortly after establishment. No stands under investigation were previously fertilized, but those stands in the 16-18 and 23-25 year-old age class were previously commercially thinned. Competing understory vegetation is predominant in all age classes. Common understory species include Andropogon virginicus, Quercus alba, Acer rubrum, Pinus virginiana, Nyssa sylvatica, Sassafras albidum, and Quercus coccinea. Soils are moderately well-drained to well drained and deep, formed in residuum from metamorphic rocks (sericite schist, graphitic schist, and/or phyllite). Specific soil series and taxonomic classifications for all sites were mapped as Spears Mountain series: fine, mixed, semiactive, mesic Typic Hapludults, or Tatum series: fine, mixed, semiactive, thermic Typic Hapludults (Soil Survey Staff, accessed Nov. 27, 2015).

\subsection{Experimental Design}

To assess the effects of forest age and season on $\mathrm{R}_{\mathrm{H}}: \mathrm{R}_{\mathrm{S}}$, stands representing a range of extensively managed loblolly pine ages and stand characteristics were selected (Table 1). Four age classes were chosen for this study and included 2- to 3-, 7- to 9-, 16- to 18-, and 23- to 25year-old stands. Classes were based on the age of stands during the 2014 growing season. The 
study was designed as a randomized complete block, where each of the four stand age classes was replicated three times, for a total of 12 stands dispersed across four geographical blocks.

\subsection{Study Installation}

In March 2014, permanent fixed area measurement plots (radius=12.62 m; area=500 $\mathrm{m}^{2}$ ) representative of the forest stand were installed in each replicate stand. To account for withinstand variability, three measurement subsamples were randomly installed within each measurement plot. To partition $\mathrm{R}_{\mathrm{S}}$, root exclusion cores constructed from steel conduit pipe (11.43 cm diameter $\mathrm{x} 35 \mathrm{~cm}$ length) were installed to sever roots in each subsample location within each treatment plot. Root biomass below $35 \mathrm{~cm}$ is assumed to be minimal at these sites and $R_{S}$ is assumed negligible below depths of $30 \mathrm{~cm}$ (Warembourg and Paul 1973). Cores were driven vertically into the soil until the top was flush with the mineral soil surface. Prior to core installation, the $\mathrm{O}$ horizon (forest floor) was temporarily removed from the installation location to avoid driving organic matter into the soil profile or inside the core, and carefully replaced after installation. To measure seasonal variation of efflux components, root exclusion cores were installed 90-days prior to $\mathrm{R}_{\mathrm{S}}$ and $\mathrm{R}_{\mathrm{H}}$ measurements during five separate periods (March, June, September, and November of 2014, and March of 2015). $\mathrm{R}_{\mathrm{H}}$ measurements were made 90 days post installation, when carbohydrate supply to roots is depleted, and $\mathrm{R}_{\mathrm{A}}$ efflux inside the pipe is assumed to be zero (Heim et al. 2015), thereby providing an independent measure of $R_{H}$.

\section{4. $R_{S}$ and $R_{H}$ Measurements}


$R_{S}$ and $R_{H}$ measurements occurred once, seasonally from June 2014 through July 2015. Measurements were taken between 9:00 and 16:00, moving systematically from experimental blocks 1-3, using a LiCor 6200 (LiCor Inc., Lincoln, Nebraska) closed dynamic system with a LiCor 6250 infrared gas analyzer (IRGA) and attached chamber (6400-09) with an area of 71.5 $\mathrm{cm}^{2}$ and volume of $926 \mathrm{~cm}^{3}$. Measurements were logged for 30s following $\mathrm{CO}_{2}$ equilibration within the chamber. Three subsample measurements were taken in each plot for $R_{S}$ and $R_{H}$, for a total of six measurements per treatment plot. A vegetation-free location was chosen adjacent to the root exclusion core for measurements of $\mathrm{R}_{\mathrm{S}}$. The LiCor chamber was placed directly over the soil surface for $R_{S}$ measurements, and over the root exclusion core for $R_{H}$ measurements. A single plot mean for each efflux component was calculated from the three subsample measurements. The relative contribution of $\mathrm{R}_{\mathrm{H}}$ to $\mathrm{R}_{\mathrm{S}}$, or partitioning coefficient, was determined by dividing the $\mathrm{R}_{\mathrm{H}}$ rate by $\mathrm{R}_{\mathrm{S}}$ to represent the percentage contribution to $\mathrm{R}_{\mathrm{S}}$.

\subsection{Soil temperature and moisture measurements}

Individual spot measurements of soil temperature $(2$ and $10 \mathrm{~cm})$ and soil volumetric water content $(\mathrm{VWC})(0-12 \mathrm{~cm})$ were made inside and adjacent to the root-exclusion core at each subsample location following the set of $\mathrm{R}_{\mathrm{S}}$ and $\mathrm{R}_{\mathrm{H}}$ measurements. Soil temperature was measured using a digital thermometer. Percent volumetric soil moisture was measured using a hydrosense soil-water sensor (Campbell Scientific USA, Logan, UT). Mean air temperature and relative humidity $(\mathrm{RH})$ were measured directly above the $\mathrm{CO}_{2}$ efflux measurement locations using an Amprobe THWD-5 RH and temperature meter (Danaher Corporation USA, Everett, WA). 


\subsection{Stand Measurements}

Standard site characteristics were measured for each measurement plot. Measurements included stem density, tree height, and diameter at breast height (DBH at $1.3 \mathrm{~m}$ ) for all stems $>1$ $\mathrm{cm} \mathrm{DBH}$, tree species, understory vegetation species and biomass, and peak leaf area index (LAI). Leaf area index data were estimated for each measurement plot using the LiCor LAI2200 Plant Canopy Analyzer positioned $1.0 \mathrm{~m}$ above the ground during late summer (September 2014). Stem biomass estimates were determined using the National Biomass Estimator (NBE) model (Jenkins et al. 2003) for Pinus species (equation 1) and mixed hardwood species (equation 2), where aboveground stem biomass $\left(\mathrm{B}_{\mathrm{D}}\right)$ is oven dry weight $(\mathrm{kg})$ and $\mathrm{DBH}$ is in centimeters:

$B_{D}=e^{-2.5356+2.4349(\ln (D B H))}$

$B_{D}=e^{-2.4800+2.4835(\ln (D B H))}$

The NBE is a conservative and well-documented national model and is generally considered the standard biomass equation used nationwide by researchers and agencies to estimate tree- and stand-level forest biomass, including the official greenhouse gas inventories for the United States (EPA 2008).

Woody and herbaceous understory vegetation was sampled at three subsample locations in each treatment plot using a $0.25 \mathrm{~m}^{2}$ quadrat and composited. Samples were oven dried at 65 
${ }^{\circ} \mathrm{C}$ until a constant mass was achieved, and dry biomass weights for each treatment plot was scaled to biomass in $\mathrm{kg} \mathrm{ha}^{-1}$.

\subsection{Soil Sampling}

Mineral soil samples were collected within each treatment plot in October, 2014. Soils were sampled from depths of 0-10 cm, $10-20 \mathrm{~cm}$, and 20-30 cm from three subsample locations in each treatment plot and composited by depth and plot. Soil samples were stored on ice and transported back to the laboratory within $24 \mathrm{~h}$ of collection. Composited soil samples were mixed and all visible roots, litter, and identifiable organic matter were removed. Bulk density was estimated using a 5-cm-diameter slide hammer with core sampler. Sequential soil cores (0$10 \mathrm{~cm}, 10-20 \mathrm{~cm}$, and 20-30 cm depths) were collected from three points in each treatment plot. The O horizon (forest floor) was sampled at the same three points within each of the 12 treatment plots using a $0.1 \mathrm{~m}^{2}$ quadrat. The collected $\mathrm{O}$ horizon samples were placed in paper bags, returned to the laboratory, and oven-dried at $65^{\circ} \mathrm{C}$ to a constant mass.

\subsection{Laboratory Analysis}

Bulk density soil samples were first oven-dried at $105^{\circ} \mathrm{C}$ for $24 \mathrm{~h}$, then passed through a 2-mm sieve to remove coarse fragments and woody debris. Total mass of soil and coarse fragments (>2 mm) were recorded and divided by the sampled volume to calculate bulk density. Following determination of bulk density, organic matter content (\% OM) was determined by loss on ignition (LOI), where approximately $10 \mathrm{~g}$ of oven-dry, sieved soil was placed in a muffle 
furnace and $380^{\circ} \mathrm{C}$ for 24 hours, then reweighed. The difference in weight before and after ignition represents the amount of the OM present in the sample (Ben-Dor and Banin 1989).

The composited soil subsamples were air-dried for $24 \mathrm{~h}$ and passed through a 2-mm sieve. A $1 \mathrm{~g}$ air-dry sample was added to a graphite crucible and analyzed for total $\mathrm{C}$ and $\mathrm{N}$ on a CNS Elemental analyzer (LECO Corporation, St. Joseph, MI). Results are reported on an ovendry $\left(105^{\circ} \mathrm{C}\right)$ basis. $\mathrm{C}$ content $\left(\mathrm{t} \mathrm{ha}^{-1}\right)$ was then determined by $\mathrm{C}$ concentration $(\%)$ and soil bulk

density $\left(\mathrm{g} \mathrm{cm}^{-3}\right)$ for each depth (cm) (Lal et al. 2001). An aliquot of each composited subsample from each depth was sent to the Virginia Tech Soil Testing Laboratory for analysis of $\mathrm{pH}$, cation exchange capacity, soluble salts, and extractable nutrients using the Mehlich-1 $(0.05 \mathrm{~N} \mathrm{HCl}+$ $0.025 \mathrm{~N} \mathrm{H}_{2} \mathrm{SO}_{4}$ ) extraction procedure (Maguire and Heckendorn 2014). Soil $\mathrm{pH}$ and nutrient concentrations at installation are summarized in Table 2.

\subsection{Statistical Analysis}

All statistical analyses were performed using JMP® 11 software system (SAS Institute, Cary, NC, USA). This study was analyzed as a randomized complete block design $(\mathrm{n}=3)$. One treatment plot per stand represents the experimental unit, and subsamples were averaged as the estimate for each experimental unit. All variables were transformed as appropriate to meet assumptions of normality. To assess the effect of stand age on $\mathrm{CO}_{2}$ efflux components, a repeated measures analysis of variance was performed and blocked for random effects, using restricted maximum likelihood (REML) estimations. Treatment differences were determined from the $95 \%$ confidence intervals about the least square (LS) means $(\alpha=0.05)$, and treatment means were tested at a significance level of $\alpha=0.05$ using Tukey-Kramer Honestly Significant 
Difference (HSD). Analyses were conducted using plot level means for all measurements and for data separated by season. Pearson correlation analysis was performed to analyze the relationships between site characteristics and $\mathrm{CO}_{2}$ efflux components.

\section{Results}

\subsection{Site Characteristics}

Many stand characteristics were significantly different $(P<0.05)$ across stand ages (Table 1), while few soil characteristics differed significantly by stand age (Table 2). Peak LAI, stem density, basal area, stem volume, stem biomass and forest floor biomass differed among stand age classes, while understory biomass did not significantly differ among age classes due to the high variability among plots within stand age classes (Table 1).

Soil characteristics that differed among age classes were limited to soil $\mathrm{pH}, \mathrm{C}: \mathrm{N}$, and organic matter percent (Table 2). Soil $\mathrm{pH}$ in the $0-10 \mathrm{~cm}$ depths was highest in the three-year age class, and significantly lower in the 25 year-age class. Soil $\mathrm{pH}$ in $10-20 \mathrm{~cm}$ depths was highest in the nine-year age classes and significantly lower in the 25 age class. Organic matter percent significantly differed among age classes in the $20-30 \mathrm{~cm}$ depth only, and was highest in the 18 year age class and lowest in the three-year age class.

\subsection{Environmental Conditions}


During the duration of the experiment (June 2014 - July 2015) measurements of mean soil temperature near measurement cores ranged from 3.04 to $28^{\circ} \mathrm{C}$ at $2 \mathrm{~cm}$ depth and 3.3 to $26^{\circ} \mathrm{C}$ at $10 \mathrm{~cm}$ depth (Figure 3). Soil moisture inside the root exclusion core ranged from 6.8 to 20.1 percent VWC and from 2.8 to 19.9 percent VWC adjacent to measurement cores (Figure 3). Mean air temperature near measurement cores ranged from 3.6 to $38.1^{\circ} \mathrm{C}$, and relative humidity ranged from 18.3 to 83.7 percent. Mean soil moisture, soil temperature, air temperature, and relative humidity did not covary in the analysis with $\mathrm{R}_{\mathrm{H}}: \mathrm{R}_{\mathrm{S}}(P>0.10$ for all variables). Soil moisture measurements taken inside and outside the root exclusion pipes were not significantly different $(P=0.125)$.

\section{3. $R_{H}: R_{S}$}

A repeated measures ANOVA analysis revealed a significant stand age effect on $R_{H}: R_{S}$ ( $P<0.0001)$, but no stand age effect on $\mathrm{R}_{\mathrm{S}}(P=0.678)$. The analysis also revealed a significant effect of season on $\mathrm{R}_{\mathrm{H}}: \mathrm{R}_{\mathrm{S}}(P<0.001)$ and $\mathrm{R}_{\mathrm{S}}(P<0.001)$. The interaction between stand age and season was not significant $(P=0.202)$.

Our results demonstrate a stepwise decrease in $\mathrm{R}_{\mathrm{H}}: \mathrm{R}_{\mathrm{S}}$ with increasing stand age. Mean $R_{H}: R_{S}$ by age class ranged from a high of $0.82 \pm 0.06$ for the three-year-old age class to a low of $0.50 \pm 0.03$ in the 25 -year-old age class (Figure 1). The $R_{H}$ proportion was $0.73 \pm 0.05$ in the nine-year-old age class and $0.59 \pm 0.05$ in the 18-year-old age class. Age class three significantly differed from age class 18 and $25(P<0.05)$, but did not differ from age class nine (Figure 1a). The mean $\mathrm{R}_{\mathrm{H}}$ proportion of all measured stand ages and seasons was 0.67 . 
$R_{H}: R_{S}$ ranged from a high of $0.85 \pm 0.06$ in the winter season, to a low of $0.56 \pm 0.04$ and $0.55 \pm 0.05$ in the summer 2014 and 2015 seasons, respectively. The $R_{H}$ proportions for fall 2014 was $0.59 \pm 0.06$ and $0.75 \pm 0.04$ for spring 2015 . Winter $R_{H}$ proportions were significantly different from fall and summer measurements $(P<0.05)$, but not from spring measurements (Figure 1b). It is important to note that while the winter and spring seasons exhibited the highest proportion of $R_{H}$ to $R_{S}$, they also had the lowest rate of $R_{S}$ and relative value of $R_{H}$ with rates of $0.05 \mu \mathrm{mol} \mathrm{m} \mathrm{s}^{-1}$, and $0.03 \mu \mathrm{mol} \mathrm{m} \mathrm{s}^{-1}$, respectively (Figure 2). Summer (averaged between the two summer sample years) and Fall seasons had the highest total soil $\mathrm{CO}_{2}$ efflux rates of 7.00 $\mu \mathrm{mol} \mathrm{m} \mathrm{m}^{-2}$ and $7.44 \mu \mathrm{mol} \mathrm{m} \mathrm{s}^{-1}$, respectively, despite having the lowest $R_{H}: R_{S}$ proportion of 0.55 for the averaged summer seasons and 0.59 for the fall season (Figure 1b).

3.4. Relationship among site characteristics and $\mathrm{R}_{\mathrm{H}}: \mathrm{R}_{\mathrm{S}}$

We analyzed relationships between $\mathrm{R}_{\mathrm{H}}: \mathrm{R}_{\mathrm{S}}$ and site characteristics using Pearson's correlation. Many site characteristics were significantly correlated with the proportion of $\mathrm{R}_{\mathrm{H}}$ to $\mathrm{R}_{\mathrm{S}}$ in all seasons (Table 3$)$. There were highly significant $(P<0.001)$ and strong $(r>0.5)$ correlations between $\mathrm{R}_{\mathrm{H}}: \mathrm{R}_{\mathrm{S}}$ and peak LAI, stem volume, and understory biomass in spring, summer, and winter seasons, stem biomass in summer and winter seasons, basal area in summer seasons, and in forest floor biomass in the winter season. All of these correlations were negative except for understory biomass. Other correlations were significant at higher alpha levels as indicated in Table 3.

\section{Discussion}




\subsection{Stand age effects on $R_{H}: R_{S}$}

Our results indicate that $\mathrm{R}_{\mathrm{H}}: \mathrm{R}_{\mathrm{S}}$ change with loblolly pine stand age, which could influence the attainment of a positive, annual net carbon $(C)$ balance $(N E P) . R_{H}: R_{S}$ decreased with increasing stand age, which supports our hypothesis. In proportion to $\mathrm{R}_{\mathrm{S}}, \mathrm{R}_{\mathrm{H}}$ decreased from 73 to $82 \%$ in young, open-canopy stands to 50 to $59 \%$ in older, closed-canopy stands. This pattern is consistent with previous studies assessing the change in $R_{A}$ and $R_{H}$ with stand development of various forest types, that report decreases in $\mathrm{R}_{\mathrm{H}}$ from 70 to $95 \%$ in young, regenerating stands, to 20 to $40 \%$ in mature forests (Bond-Lamberty et al. 2004a, Epron et al. 2006, Noormets et al. 2012).

The pattern of decreasing $\mathrm{R}_{\mathrm{H}}: \mathrm{R}_{\mathrm{S}}$ with increasing stand age is attributed to major structural changes resulting from stand development that alter the balance between $\mathrm{C}$ fixation and respiration. Young loblolly pine stands are typically $\mathrm{C}$ sources due to high soil $\mathrm{CO}_{2}$ efflux rates relative to gross $\mathrm{CO}_{2}$ canopy assimilation rates (Maier et al. 2004, Gough et al. 2005, Sampson et al. 2006) and higher $R_{H}: R_{S}$ proportions associated with decomposition of harvest residues, inputs of dead organic matter into the soil, and subsequent changes in the soil microclimate and substrate availability following harvests (Noormets et al. 2012). Higher $\mathrm{R}_{\mathrm{H}}$ in younger stands has also been attributed to higher substrate availability (Parmelee et al 1989 and Bhupinderal-Singh et al 2003). Mature loblolly pine stands are thought to be C sinks (Hamilton et al. 2002, Lai et al. 2002, Schafer et al. 2003) that decline in strength with decreases in stand LAI (Albaugh et al. 2004) and NPP (Sampson et al 2006, 2008) as stands mature. Additionally, the relative contribution of $\mathrm{R}_{\mathrm{A}}$ has been shown to increase with stand age reflecting an increase in NPP and 
root biomass (Ewel et al. 1987), resulting in a decrease in the proportion of $R_{H}$ to $R_{S}$ with increasing stand age. The strong, negative correlation between $R_{H}: R_{S}$ and peak LAI, stem volume, and stem biomass stand variables reported in Table 3, support the notion that as aboveground, and presumably belowground biomass increases with stand age, the proportion of $\mathrm{R}_{\mathrm{A}}$ increases thereby resulting in a decrease in $\mathrm{R}_{\mathrm{H}}: \mathrm{R}_{\mathrm{S}}$ with stand development. Conversely, understory biomass was strongly, negatively correlated with $\mathrm{R}_{\mathrm{H}}: \mathrm{R}_{\mathrm{S}}$. This may be a result of competition between understory and overstory vegetation, as understory vegetation and stem biomass are moderately, negatively correlated $(r=-0.34, P=0.033)$. Therefore, as understory biomass increases, the proportion of $\mathrm{R}_{\mathrm{H}}: \mathrm{R}_{\mathrm{A}}$ may increase as a result of reduced overstory aboveand belowground biomass. Alternatively, greater understory biomass may increase fine root biomass, turnover, and inputs, thereby increasing substrate availability and stimulating microbial activity with consequent increases in $\mathrm{R}_{\mathrm{H}}$.

\subsection{Seasonal variation in partitioning $R_{H}: R_{S}$}

We observed significant seasonality of the proportion of $R_{H}$ to $R_{S}$ over the duration of this study. The lowest proportion of $\mathrm{R}_{\mathrm{H}}: \mathrm{R}_{\mathrm{S}}$ was in the summer seasons, when the contribution of $\mathrm{R}_{\mathrm{A}}$ to $\mathrm{R}_{\mathrm{S}}$ is often higher (Bond-Lamberty et al. 2004a, Wieser and Bahn 2004). This is assumed to reflect a higher temperature sensitivity for $\mathrm{R}_{\mathrm{A}}$ than $\mathrm{R}_{\mathrm{H}}$ (Boone et al. 1998, Bond-Lamberty et al. 2004), or higher root biomass in the growing season (Bahn et al. 2006, Saiz et al. 2006). Our highest observed proportion of $R_{H}$ to $R_{S}$ were in winter and spring months. This could reflect the lower temperature sensitivity of $\mathrm{R}_{\mathrm{H}}$ (Bond-Lamberty et al. 2004), or reflect increased substrate 
availability for soil microbial communities (Davidson and Janssens 2006), or the seasonal decline in $\mathrm{R}_{\mathrm{A}}$ (Wieser and Bahn 2004).

\subsection{Regional comparison of $R_{H}: R_{S}$ estimates}

The reported $\mathrm{R}_{\mathrm{H}}: \mathrm{R}_{\mathrm{S}}$ in this study are lower than the reported proportions for other forest ecosystems in the southeast that used comparable root exclusion core methods (Strahm et al. 2014, Heim et al. 2015, Archmiller and Samuelson 2016). Additionally, this study evaluated $\mathrm{R}_{\mathrm{H}}$ across various stand ages, while previous regional studies evaluated $R_{H}$ to $R_{S}$ in one age class. We report a range of 0.83 to 0.50 of decreasing $R_{H}: R_{S}$ with loblolly pine stand age, with a mean $\mathrm{R}_{\mathrm{H}}$ proportion of all measured stand ages and seasons of 0.67 . This is comparable to the mean ratio of $R_{H}$ to $R_{S}$ of $0.60 \pm 0.12$ across temperature coniferous forests (Subke et al. 2006). Archmiller and Samuelson (2016) evaluated the proportion of $R_{H}$ to $R_{S}$ in 26-year-old longleaf pine (Pinus palustris Mill.) stands in western Georgia and reported a range of 0.66 to 0.82 dependent upon whether $\mathrm{R}_{\mathrm{H}}$ was corrected for root decay inside root exclusion cores. Heim et al. (2015) reported a $\mathrm{R}_{\mathrm{H}}: \mathrm{R}_{\mathrm{S}}$ proportion of $0.79 \pm .005$ in in an eight-year-old loblolly pine plantation in VA. Similarly, Strahm et al (2014) reported a Southeast region-wide estimate for mid rotation (nine-10-year old) loblolly pine stands of $0.840 \pm 0.026$. In this study, our mid-rotation loblolly pine stands (age nine) had a mean $R_{H}$ to $R_{S}$ proportion of $0.73 \pm 0.03$.

The higher proportion of $\mathrm{R}_{\mathrm{H}}$ observed in similarly aged loblolly pine stands is hypothesized to be a result of management intensity and competition control. The stands investigated for the Southeast region-wide $\mathrm{R}_{\mathrm{H}}: \mathrm{R}_{\mathrm{S}}$ estimate received intensive competition control one year prior to study installation and the start of respiration measurements. Both mechanical 
clearing and broadcast herbicide treatments were applied to control hardwood, volunteer pine, and herbaceous competition. Subsequent, annual chemical control applications were applied as needed to keep the understory clear of competing vegetation. Conversely, the stands in this study received no competition control following the initial mechanical clearing and broadcast herbicide treatment at stand initiation, resulting in prevalent woody and herbaceous competing vegetation in all age classes. Implementation of competition control after stand establishment reduces competing vegetation volume and understory biomass, likely resulting in lower relative $\mathrm{R}_{\mathrm{A}}$ contributions to $R_{S}$ in intensively managed systems, compared to extensively managed systems without competition control.

\section{Conclusions}

The proportion of $R_{H}$ to $R_{S}$ in loblolly pine varied from approximately 0.83 to 0.55 , dependent upon the stand age and season. The results of this study, when combined with other region-wide estimates of the contribution of $R_{H}$ to $R_{S}$ in managed loblolly pine stands, demonstrate the need to account for site- and stand-specific characteristics, such as stand age, season, and management intensity, when modeling $\mathrm{R}_{\mathrm{H}}$ in ecosystem $\mathrm{C}$ models. The range in available $R_{H}: R_{S}$ estimates suggest $C$ sequestration capacities of these systems are highly varied and dependent upon site-specific conditions. Existing efforts to model ecosystem C or NEP assume that soil respiration is evenly partitioned between $\mathrm{R}_{\mathrm{H}}$ and $\mathrm{R}_{\mathrm{A}}$, while regional estimates of loblolly pine suggest $\mathrm{R}_{\mathrm{H}}$ comprises a greater proportion of $\mathrm{R}_{\mathrm{S}}$ in most age-classes. Over- or under-estimating $\mathrm{R}_{\mathrm{H}}: \mathrm{R}_{\mathrm{S}}$ in ecosystem $\mathrm{C}$ models has important implications for estimates of $\mathrm{C}$ sequestration, and for identifying when forests switch from functioning as a $\mathrm{C}$ source to a $\mathrm{C}$ sink. 
Larger estimates of $\mathrm{R}_{\mathrm{H}}$ suggest more fixed $\mathrm{C}$ is released back to the atmosphere than stored in the system. Incorporation of these results into existing models will enable more accurate estimates of C sequestration potential of planted pine in the southeastern US.

\section{Acknowledgements}

We would like to thank John Peterson, Ilia Donner, and Brian Parr for providing field and laboratory assistance, and Michael Womack and Thomas Zaebst of the Virginia Department of Forestry for logistical assistance with this study. Additionally, we thank the thoughtful reviews from anonymous reviewers on the final draft of this manuscript. This research was supported by the Pine Integrated Network: Education, Mitigation, and Adaptation Project (PINEMAP), a Coordinated Agricultural Project funded by the US Department of Agriculture (USDA) National Institute of Food and Agriculture (NIFA), Award No. 2011-68002-30185. 


\section{References}

Albaugh, T. J., H. L. Allen, P. M. Dougherty, and K. H. Johnsen. 2004. Long term growth responses of loblolly pine to optimal nutrient and water resource availability. Forest Ecology and Management 192:3-19.

ArchMiller, A., and L. Samuelson. 2016. Partitioning Longleaf Pine Soil Respiration into Its Heterotrophic and Autotrophic Components through Root Exclusion. Forests 7:39.

Arneth, A., S. P. Harrison, S. Zaehle, K. Tsigaridis, S. Menon, P. J. Bartlein, J. Feichter, A. Korhola, M. Kulmala, D. O'Donnell, G. Schurgers, S. Sorvari, and T. Vesala. 2010. Terrestrial biogeochemical feedbacks in the climate system. Nature Geosci 3:525-532.

Bahn, M., M. Knapp, Z. Garajova, N. Pfahringer, and A. Cernusca. 2006. Root respiration in temperate mountain grasslands differing in land use. Global Change Biology 12:9951006

Bhupinderpal-Singh, A. N., M. O. Löfvenius, M. N. Högberg, P. E. Mellander, and P. Högberg. 2003. Tree root and soil heterotrophic respiration as revealed by girdling of boreal Scots pine forest, extending observations beyond the first year. Plant, Cell and Environment 26: $1287-1296$.

Bond-Lamberty, B., C. Wang, and S. T. Gower. 2004a. Contribution of root respiration to soil surface CO2 flux in a boreal black spruce chronosequence. Tree Physiology 24:13871395.

Bond-Lamberty, B., C. Wang, and S. T. Gower. 2004. A global relationship between the heterotrophic and autotrophic components of soil respiration? Global Change Biology 10:1756-1766. 
Boone, R. D., K. J. Nadelhoffer, J. D. Canary, and J. P. Kaye. 1998. Roots exert a strong influence on the temperature sensitivityof soil respiration. Nature 396:570-572.

Collins, B. 2005. Thresholds of Disturbance: Land Management Effects on Vegetation and Nitrogen Dynamics. Technical Report. Oak Ridge National Laboratory: Oak Ridge, TN, USA. pp. 1-63.

Chapin III, F. S., P. A. Matson, and P. Vitousek. 2011. Principles of terrestrial ecosystem ecology. Springer Science \& Business Media.

Davidson, E. A., and I. A. Janssens. 2006. Temperature sensitivity of soil carbon decomposition and feedbacks to climate change. Nature 440:165-173.

Epron, D. 2009. Separating autotrophic and heterotrophic components of soil respiration: lessons learned from trenching and related root exclusion experiments. Soil carbon dynamicsan integrated methodology. Cambridge University Press, Cambridge:157-168.

Epron, D., Y. Nouvellon, P. Deleporte, S. Ifo, G. Kazotti, A. Thongo M'Bou, W. Mouvondy, L. S. Andre, O. Roupsard, and C. Jourdan. 2006. Soil carbon balance in a clonal Eucalyptus plantation in Congo: effects of logging on carbon inputs and soil CO2 efflux. Global Change Biology 12:1021-1031.

Ewel, K. C., W. P. Cropper. Jr, and H. L. Gholz. 1987. Soil CO2 evolution in Florida slash pine plantations. II. Importance of root respiration. Canadian Journal of Forest Research 17:330-333.

Gorte, R. W. 2009. Carbon sequestration in forests. CRS Report for Congress. Wasington, DC: Congressional Research Service.

Gough, C. M., and J. R. Seiler. 2004. The influence of environmental, soil carbon, root, and stand characteristics on soil CO2 efflux in loblolly pine (Pinus taeda L.) plantations 
located on the South Carolina Coastal Plain. Forest Ecology and Management 191:353363.

Gough, C. M., J. R. Seiler, P. E. Wiseman, and C. A. Maier. 2005. Soil CO2 efflux in loblolly pine (Pinus taeda L.) plantations on the Virginia Piedmont and South Carolina Coastal Plain over a rotation-length chronosequence. Biogeochemistry 73:127-147.

Hamilton, J. G., R. B. Thomas, and E. H. Delucia. 2001. Direct and indirect effects of elevated $\mathrm{CO}_{2}$ on leaf respiration in a forest ecosystem, Plant Cell Environ 24:975 - 982.

Han, F. X., M. J. Plodinec, Y. Su, D. L. Monts, and Z. Li. 2007. Terrestrial carbon pools in southeast and south-central United States. Climatic Change 84:191-202.

Hanson, P., N. Edwards, C. Garten, and J. Andrews. 2000. Separating root and soil microbial contributions to soil respiration: a review of methods and observations. Biogeochemistry 48:115-146.

Heim, B. C., J. R. Seiler, and B. D. Strahm. 2015. Root Nonstructural Carbohydrates and Their Relationship with Autotrophic Respiration of Loblolly Pine (Pinus taedaL.). Communications in Soil Science and Plant Analysis 46:888-896.

Heim, Brett Christopher. Partitioning soil respiration in response to drought and fertilization in loblolly pine: laboratory and field approaches.Thesis. Virginia Tech, 2014. Web. 3 Feb. 2016.

Högberg, P., A. Nordgren, N. Buchmann, A. F. Taylor, A. Ekblad, M. N. Högberg, G. Nyberg, M. Ottosson-Löfvenius, and D. J. Read. 2001. Large-scale forest girdling shows that current photosynthesis drives soil respiration. Nature 411:789-792.

Jenkins, J.C., Chojnacky, D.C., Heath, L.S., Birdsey, R.A. 2003. National-scale biomass estimators for United States tree species. Forest Science 49: 12-35. 
Johnsen, K. H., D. Wear, R. Oren, R. O. Teskey, F. Sanchez, R. Will, J. Butnor, D. Markewitz, D. Richter, and T. Rials. 2001. Meeting global policy commitments: carbon sequestration and southern pine forests. Journal of Forestry 99:14-21.

Kuzyakov, Y. 2006. Sources of CO2 efflux from soil and review of partitioning methods. Soil Biology and Biochemistry 38:425-448.

Lai, C.T., G. Katul, J. Butnor, D. Ellsworth, and R. Oren. 2002. Modelling night-time ecosystem respiration by a constrained source optimization method. Global Change Biology 8:124141

Lal, R., Kimble, J.M., Follett, R.F., Stewart, B.A., eds. 2001.Assessment methods for soil carbon.Boca Raton, FL: Lewis Publishers.Robertson, G.P., Coleman, D.C., Bledsoe, C.S., Sollins, P. 1999. Standard methods for long-term ecological research. Oxford, U.K: Oxford University Press.

Landsberg, J., and R. Waring. 1997. A generalised model of forest productivity using simplified concepts of radiation-use efficiency, carbon balance and partitioning. Forest ecology and management 95:209-228.

Lavigne, M. B., R. Boutin, R. J. Foster, G. Goodine, P. Y. Bernier, and G. Robitaille. 2003. Soil respiration responses to temperature are controlled more by roots than by decomposition in balsam fir ecosystems. Canadian Journal of Forest Research 33:1744-1753.

Lee, M. s., K. Nakane, T. Nakatsubo, W. h. Mo, and H. Koizumi. 2002. Effects of rainfall events on soil $\mathrm{CO} 2$ flux in a cool temperate deciduous broad-leaved forest. Ecological Research 17:401-409.

Lovett, G. M., J. J. Cole, and M. L. Pace. 2006. Is Net Ecosystem Production Equal to Ecosystem Carbon Accumulation? Ecosystems 9:152-155. 
Maier, C. A., T. J. Albaugh, H. Lee Allen, and P. M. Dougherty. 2004. Respiratory carbon use and carbon storage in mid-rotation loblolly pine (Pinus taeda L.) plantations: the effect of site resources on the stand carbon balance. Global Change Biology 10:1335-1350.

Maguire, R.; Heckendorn, S. Explanation of Soil Tests; Virginia Cooperative Extension Publication 452-701. Available online: http://pubs.ext.vt.edu/452/452-701/452-701.html (accessed on 13 November 2015).

Noormets, A., S. G. McNulty, J.-C. Domec, M. Gavazzi, G. Sun, and J. S. King. 2012. The role of harvest residue in rotation cycle carbon balance in loblolly pine plantations. Respiration partitioning approach. Global Change Biology 18:3186-3201.

Parmelee, R. W., M. H. Beare, and J. M. Blair. 1989. Decomposition and nitrogen dynamics of surface weed residues in no-tillage agroecosystems under drought conditions: influence of resource quality on the decomposer community. Soil Biol. Biochem. 21:97-103.

Parton, W. J., J. W. Stewart, and C. V. Cole. 1988. Dynamics of C, N, P and S in grassland soils: a model. Biogeochemistry 5:109-131.

Prestemon, J. P., and R. C. Abt. 2002. Timber Products Supply and Demand. In: Wear, D.N.; Greis, J.G., The Southern Forest Resource Assessment. General Technical Report GTRSRS-53. U.S. Department of Agriculture Forest Service, Southern Research Station, Asheville, North Carolina. pp. 299-325.

Randerson, J., F. Chapin III, J. Harden, J. Neff, and M. Harmon. 2002. Net ecosystem production: a comprehensive measure of net carbon accumulation by ecosystems. Ecological applications 12:937-947. 
Rey, A., E. Pegoraro, V. Tedeschi, I. De Parri, P. G. Jarvis, and R. Valentini. 2002. Annual variation in soil respiration and its components in a coppice oak forest in Central Italy. Global Change Biology 8:851-866.

Saiz, G., K. Byrne, K. Butterbach-Bahl, et al. 2006. Stand-age related effects on soil respiration in a first rotation Sitka spruce chronosequence in central Ireland. Global Change Biology, 12:1007-20

Sampson, D., R. Waring, C. Maier, C. Gough, M. J. Ducey, and K. Johnsen. 2006. Fertilization effects on forest carbon storage and exchange, and net primary production: A new hybrid process model for stand management. Forest Ecology and Management 221:91-109.

Sampson, D. A., I. A. Janssens, and R. Ceulemans. 2001. Simulated soil CO \$_2 \$ efflux and net ecosystem exchange in a 70-year-old Belgian Scots pine stand using the process model SECRETS. Annals of Forest Science 58:31-46.

Sampson, D. A., R. H. Wynne, and J. R. Seiler. 2008. Edaphic and climatic effects on forest stand development, net primary production, and net ecosystem productivity simulated for Coastal Plain loblolly pine in Virginia. Journal of Geophysical Research: Biogeosciences

\section{3.}

Singh, J., and S. Gupta. 1977. Plant decomposition and soil respiration in terrestrial ecosystems. The Botanical Review 43:449-528.

Strahm, B., Seiler, J., Heim, B., Will, R., Ausmus, C., Vogel, J. Lokuta, G. Jokela, E. 2014. Partitioning Soil Respiration to Quantify Carbon Sequestration: A Regional Synthesis of Fertilization and Throughfall Reduction. PINEMAP Annual Report 3:20-21. 
Soil Survey Staff, Natural Resources Conservation Service, United States Department of Agriculture. Soil Series Classification Database. Available online. Accessed [November/27/2015].

Subke, J.A., I. Inglima, and M. Francesca Cotrufo. 2006. Trends and methodological impacts in soil CO2 efflux partitioning: A metaanalytical review. Global Change Biology 12:921943.

U.S. Environmental Protection Agency [US EPA]. 2008. Inventory of U.S. greenhouse gas emissions and sinks: 1990-2006. EPA 430-R-08-005. Washington, DC: U.S. Environmental Protection Agency, Office of Atmospheric Program.

Vogel, J. G., and D. W. Valentine. 2005. Small root exclusion collars provide reasonable estimates of root respiration when measured during the growing season of installation. Canadian Journal of Forest Research 35:2112-2117.

Warembourg, F. R. and E. A. Paul. 1973. The use of C1402 canopy techniques for measuring carbon transfer through the plant-soil system. Plant and Soil 38:331345.

Wear, D. N., and J. G. Greis. 2002. Southern forest resource assessment: summary of findings. Journal of Forestry 100:6-14.

Wieser, G., and M. Bahn. 2004. Seasonal and spatial variation of woody tissue respiration in a Pinus cembra tree at the alpine timberline in the central Austrian Alps. Trees 18:576-580.

Wiseman, P. E., and J. R. Seiler. 2004. Soil CO2 efflux across four age classes of plantation loblolly pine (Pinus taeda L.) on the Virginia Piedmont. Forest Ecology and Management 192:297-311. 


\section{Figure captions}

Figure 1: Mean heterotrophic soil respiration $\left(\mathrm{R}_{\mathrm{H}}\right)$ proportion to total soil respiration $\left(\mathrm{R}_{\mathrm{S}}\right)$ by stand age (a) and by season (b), and mean total soil respiration $\left(R_{S}\right)$ by season. $R_{H}: R_{S}$ was measured across five seasons and in four age classes of loblolly pine stands (Pinus taeda L.) in Virginia. Different letters within each category denote significant differences using Tukey’s HSD at $P<0.05$. Error bars represent \pm 1 SE.

Figure 2: Mean total soil respiration (RS) by season. RS was measured across five seasons and in four age classes of loblolly pine stands (Pinus taeda L.) in Virginia. Different letters within each category denote significant differences using Tukey's HSD at $P<0.05$. Error bars represent $\pm 1 \mathrm{SE}$.

Figure 3: Mean soil moisture inside (a) and outside (b) root-exclusion cores and soil temperature at $2 \mathrm{~cm}$ depth (b), and at $10 \mathrm{~cm}$ depth (c) measured across five seasons and in four age classes of loblolly pine stands (Pinus taeda L.) in Virginia. Error bars represent \pm 1 SE. 
Table 1. Summary of stand characteristics for four stand age classes of loblolly pine.

\begin{tabular}{|c|c|c|c|c|c|c|c|}
\hline Stand age & Peak LAI & $\begin{array}{l}\text { Stem density } \\
\left(\text { stems ha }^{-1}\right)\end{array}$ & $\begin{array}{c}\text { Basal area } \\
\left(\mathbf{m}^{2} \mathbf{h a}^{-1}\right)\end{array}$ & $\begin{array}{l}\text { Stem volume } \\
\qquad\left(\mathrm{m}^{3} \mathbf{h a}^{-1}\right)\end{array}$ & $\begin{array}{l}\text { Stem biomass } \\
\qquad\left(\mathrm{kg} \mathrm{ha}^{-1}\right)\end{array}$ & $\begin{array}{l}\text { Understory biomass } \\
\qquad\left(\mathrm{kg} \mathrm{ha}^{-1}\right)\end{array}$ & $\begin{array}{l}\text { Forest floor mass } \\
\qquad\left(\mathrm{kg} \mathrm{ha}^{-1}\right)\end{array}$ \\
\hline 3 & $0.32(0.32)^{b}$ & $1400.23(134.84)^{b}$ & $1.20(0.98) \quad b$ & $10.68(0.98)$ & $2579.99(281.08)$ & $3948.18(521.59)^{\mathrm{a}}$ & $1406.10(307.56)^{c}$ \\
\hline 9 & $2.18(0.05)^{\mathrm{a}}$ & $4892.58(699.48)^{\mathrm{a}}$ & $118.30(15.89)^{\mathrm{a}}$ & $466.96(59.24) \quad$ ab & $562806.94(9730.55)^{a b}$ & $2353.69(729.98)^{\mathrm{a}}$ & $3196.38(348.88)^{b}$ \\
\hline 18 & $2.52(0.14)^{a}$ & $3722.97(710.64)^{a b}$ & $158.09(21.74)^{\mathrm{a}}$ & $1091.68(167.19)^{\mathrm{a}}$ & $883743.26(14162.55)^{\mathrm{a}}$ & $1103.20(553.970)^{\mathrm{a}}$ & $4037.18(364.10)^{a b}$ \\
\hline 25 & $3.11(0.07)^{\mathrm{a}}$ & $2322.74(520.67)^{\mathrm{b}}$ & $150.50(28.40)^{\mathrm{a}}$ & $1179.41(322.56)^{\mathrm{a}}$ & $829481.85(17704.77)^{\mathrm{a}}$ & $3759.51(1790.37)^{\mathrm{a}}$ & $5326.13(380.79)^{\mathrm{a}}$ \\
\hline
\end{tabular}

Data represent plot means $(\mathrm{n}=3)$ and standard errors in parentheses. Stem biomass includes all stems greater than $1 \mathrm{~cm} \mathrm{DBH}$.

Lowercase letters denote significant differences $(P<0.05)$ among stand age classes. 
Table 2. Summary of soil characteristics for four stand age classes of loblolly pine at three depth increments.

\begin{tabular}{|c|c|c|c|c|c|c|c|c|c|c|c|}
\hline $\begin{array}{l}\text { Depth } \\
(\mathrm{cm})\end{array}$ & Stand age & pH & $\begin{array}{l}\text { Bulk density } \\
<2 \mathrm{~mm}\left(\mathrm{~g} \mathrm{~cm}^{-3}\right)\end{array}$ & & $\mathbf{N}(\%)$ & $\mathrm{C}(\%)$ & $\mathrm{C}: \mathrm{N}$ & $\mathrm{C}\left(\mathrm{Mg} \mathrm{ha}^{-1}\right)$ & OM $(\%)$ & $\begin{array}{c}\text { CEC } \\
\left(\mathrm{cmol}_{\mathrm{c}} \mathbf{k g}^{-1}\right)\end{array}$ & $\begin{array}{c}\text { Base } \\
\text { Saturation } \\
(\%)\end{array}$ \\
\hline \multicolumn{12}{|l|}{$0-10$} \\
\hline & 3 & $4.88(0.08)^{a}$ & $0.78(0.07)$ & a & $0.10(0.008)^{\mathrm{a}}$ & $2.59(0.12)^{\mathrm{a}}$ & $25.49(1.52)^{b}$ & $2018.56(256.07)^{a}$ & $5.70(0.73)^{a}$ & $5.40(0.28)^{\mathrm{a}}$ & $19.33(3.01)^{\mathrm{a}}$ \\
\hline & 9 & $4.76(0.09)^{\mathrm{ab}}$ & $0.85(0.05)$ & a & $0.12(0.037)^{\mathrm{a}}$ & $2.86(0.76)^{a}$ & $24.73(1.12)^{b}$ & $2397.10(546.54)^{a}$ & $5.80(0.50)^{a}$ & $5.27(0.73)^{a}$ & $16.13(4.08)^{\mathrm{a}}$ \\
\hline & 18 & $4.70(0.03)^{a b}$ & $0.67(0.06)$ & a & $0.06(0.016)^{\mathrm{a}}$ & $1.98(0.24)^{a}$ & $33.01(4.30)^{\mathrm{a}}$ & $1203.11(276.34)^{a}$ & $7.09(2.08)^{\mathrm{a}}$ & $5.47(0.53)^{\mathrm{a}}$ & $13.03(3.29)^{\mathrm{a}}$ \\
\hline & 25 & $4.28(0.18)^{\mathrm{b}}$ & $0.81(0.07)$ & a & $0.12(0.024)^{\mathrm{a}}$ & $3.58(0.86)^{a}$ & $29.94(2.41)^{a b}$ & $2892.43(580.68)^{a}$ & $5.43(0.30)^{\mathrm{a}}$ & $6.63(0.88)^{\mathrm{a}}$ & $9.27(2.32)^{\mathrm{a}}$ \\
\hline \multicolumn{12}{|l|}{$10-20$} \\
\hline & 3 & $4.99(0.06)^{\mathrm{a}}$ & $1.20(0.07)$ & a & $0.04(0.007)^{\mathrm{a}}$ & $0.91(0.15)^{\mathrm{a}}$ & $25.51(1.97)^{\mathrm{a}}$ & $1104.69(244.24)^{a}$ & $3.05(0.43)^{\mathrm{A}}$ & $3.73(0.60)^{a}$ & $16.07(3.64)^{a}$ \\
\hline & 9 & $5.03(0.08)^{\mathrm{a}}$ & $1.12(0.04)$ & a & $0.04(0.005)^{\mathrm{a}}$ & $1.10(0.11)^{\mathrm{a}}$ & $25.27(0.71)^{\mathrm{a}}$ & $1225.79(104.17)^{a}$ & $2.71(0.16)^{\mathrm{A}}$ & $3.37(0.34)^{a}$ & $15.97(2.49)^{\mathrm{a}}$ \\
\hline & 18 & $4.87(0.03)^{a b}$ & $1.13(0.20)$ & a & $0.04(0.002)^{\mathrm{a}}$ & $1.15(0.10)^{a}$ & $29.20(2.46)^{\mathrm{a}}$ & $1233.02(332.11)^{a}$ & $3.40(0.73)^{\mathrm{A}}$ & $4.67(0.18)^{\mathrm{a}}$ & $12.97(3.17)^{\mathrm{a}}$ \\
\hline & 25 & $4.68(0.03)^{b}$ & $1.32(0.26)$ & a & $0.06(0.008)^{\mathrm{a}}$ & $1.70(0.29)^{\mathrm{a}}$ & $30.04(1.33)^{\mathrm{a}}$ & $2396.67(816.83)^{a}$ & $4.09(0.43)^{\mathrm{A}}$ & $4.80(0.85)^{\mathrm{a}}$ & $10.60(1.55)^{\mathrm{a}}$ \\
\hline \multicolumn{12}{|l|}{$20-30$} \\
\hline & 3 & $4.92(0.07)^{a}$ & $1.43(0.03)$ & a & $0.03(0.003)^{\mathrm{a}}$ & $0.75(0.05)^{\mathrm{a}}$ & $22.46(2.81)^{\mathrm{a}}$ & $1069.36(62.43)^{a}$ & $1.78(0.07)^{\mathrm{b}}$ & $4.47(0.84)^{a}$ & $11.50(1.90)^{\mathrm{a}}$ \\
\hline & 9 & $4.96(0.08)^{\mathrm{a}}$ & $1.28(0.07)$ & a & $0.03(0.001)^{\mathrm{a}}$ & $0.71(0.04)^{\mathrm{a}}$ & $23.25(0.96)^{\mathrm{a}}$ & $901.24(50.36) \quad$ & $2.66(0.18)^{a b}$ & $3.67(0.86)^{a}$ & $12.87(2.39)^{\mathrm{a}}$ \\
\hline & 18 & $4.80(0.03)^{\mathrm{a}}$ & $1.32(0.13)$ & a & $0.03(0.002)^{\mathrm{a}}$ & $0.82(0.01)^{\mathrm{a}}$ & $25.09(1.29)^{\mathrm{a}}$ & $1082.33(70.99)$ & $4.06(0.43)^{\mathrm{a}}$ & $5.40(0.40)^{\mathrm{a}}$ & $10.17(1.77)^{\mathrm{a}}$ \\
\hline & 25 & $4.69(0.04)^{\mathrm{a}}$ & $1.26(0.04)$ & a & $0.04(0.003)^{\mathrm{a}}$ & $0.91(0.11)^{\mathrm{a}}$ & $23.97(1.09)^{\mathrm{a}}$ & $1133.29(114.35)^{a}$ & $3.52(0.72)^{a b}$ & $4.83(0.58)^{\mathrm{a}}$ & $9.13(0.78)^{\mathrm{a}}$ \\
\hline
\end{tabular}

Data represent plot means $(\mathrm{n}=3)$ and standard errors in parentheses. Lowercase letters denote significant differences $(P<0.05)$ among stand ages within a given soil depth. 
Table 3. Pearson's correlation coefficients for relationships between $R_{H}: R_{S}$ and stand characteristics by season.

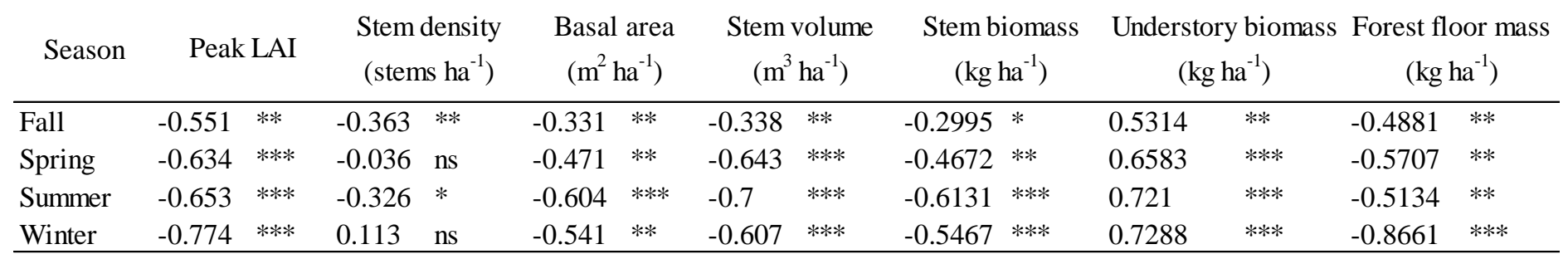

Note: $* P<0.1, * * P<0.05, * * * P<0.0001, \mathrm{~ns}=$ not significant. $\mathrm{R}_{\mathrm{H}}$, heterotrophic soil respiration; $\mathrm{R}_{\mathrm{S}}$, total soil respiration. 
a

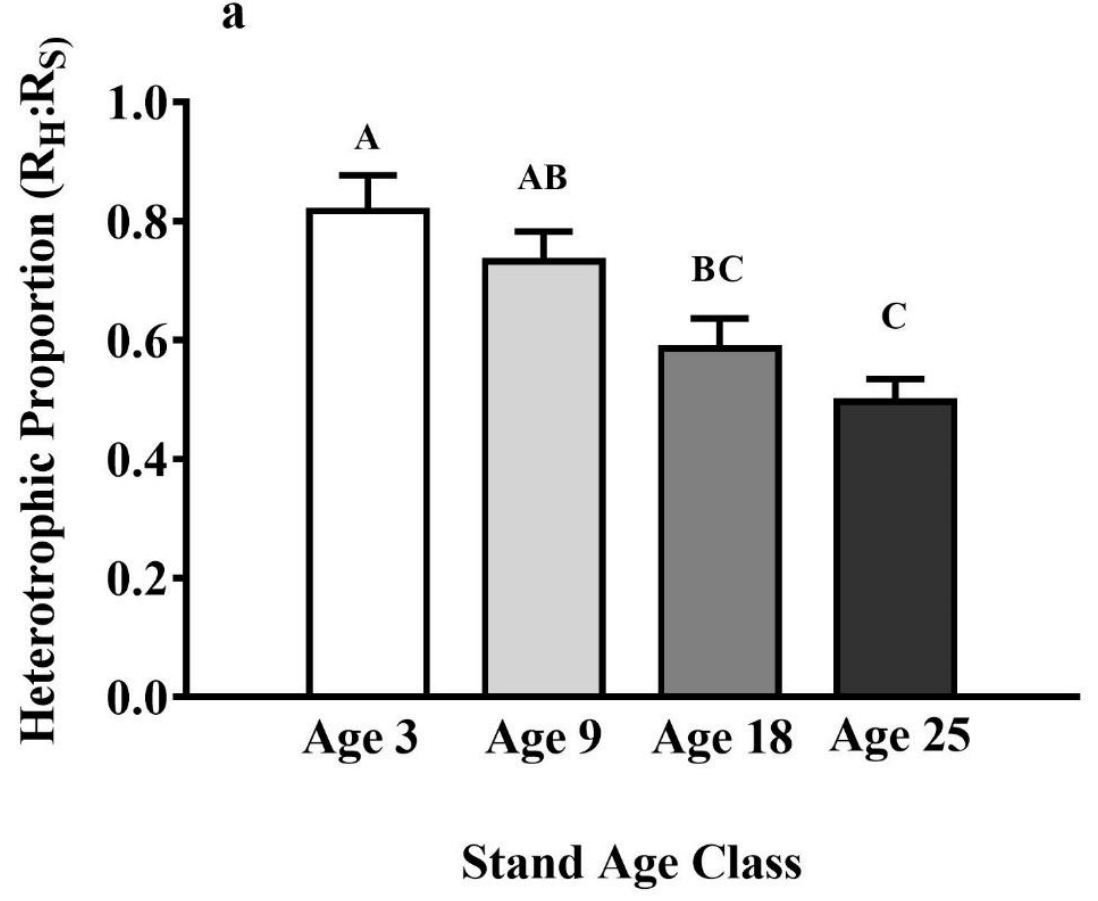

Figure 1: (2-column fitting image) b

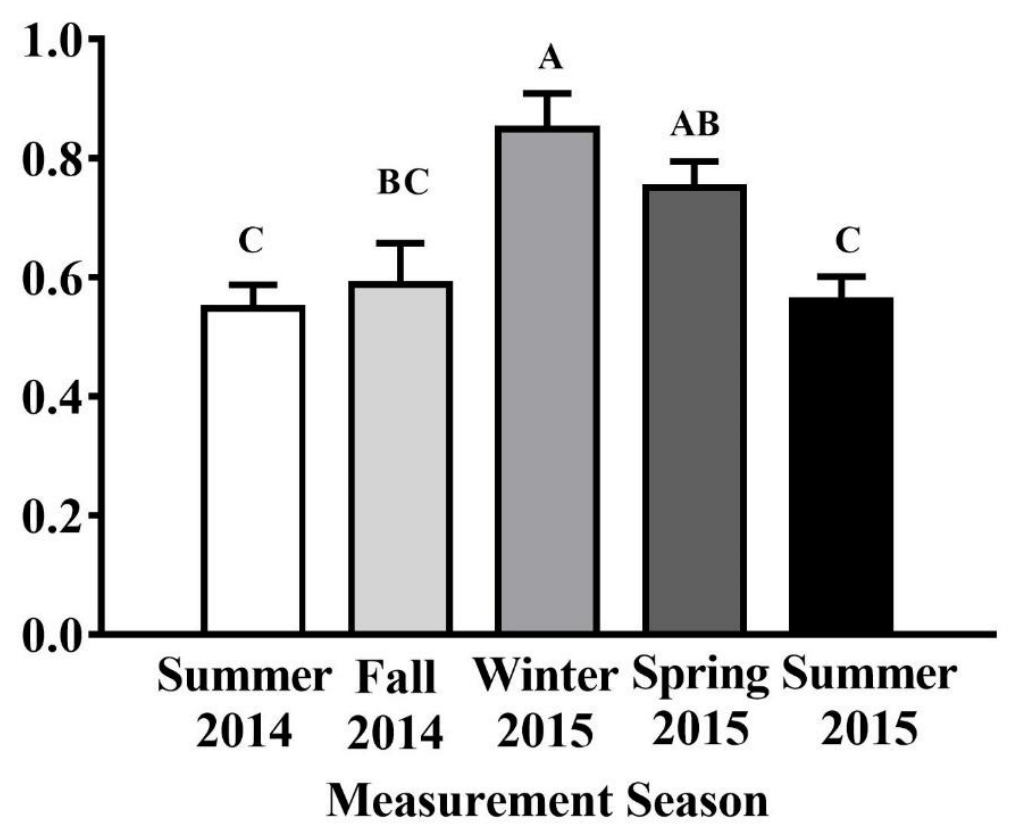




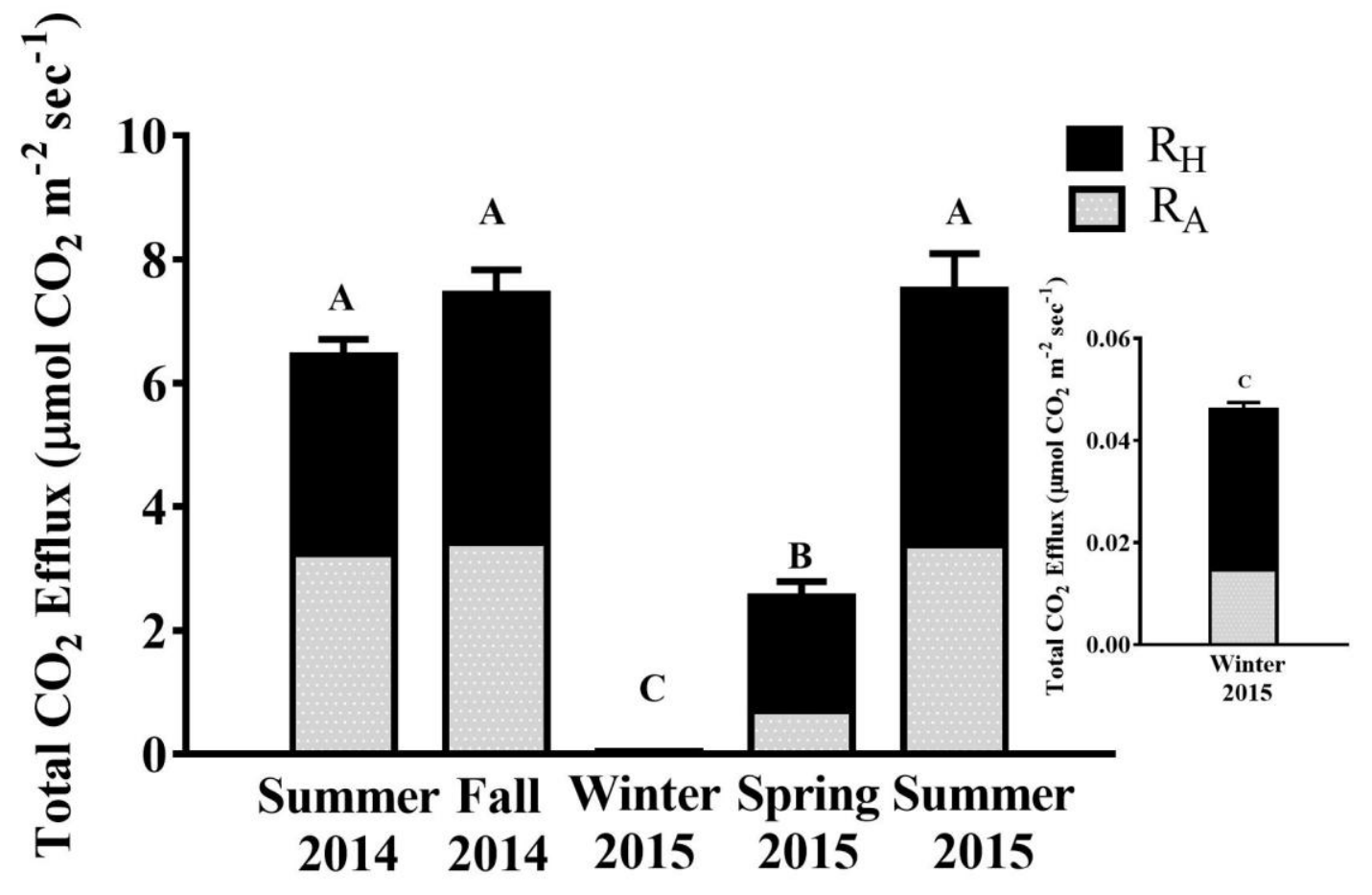

Figure 2: (single-column fitting image) 

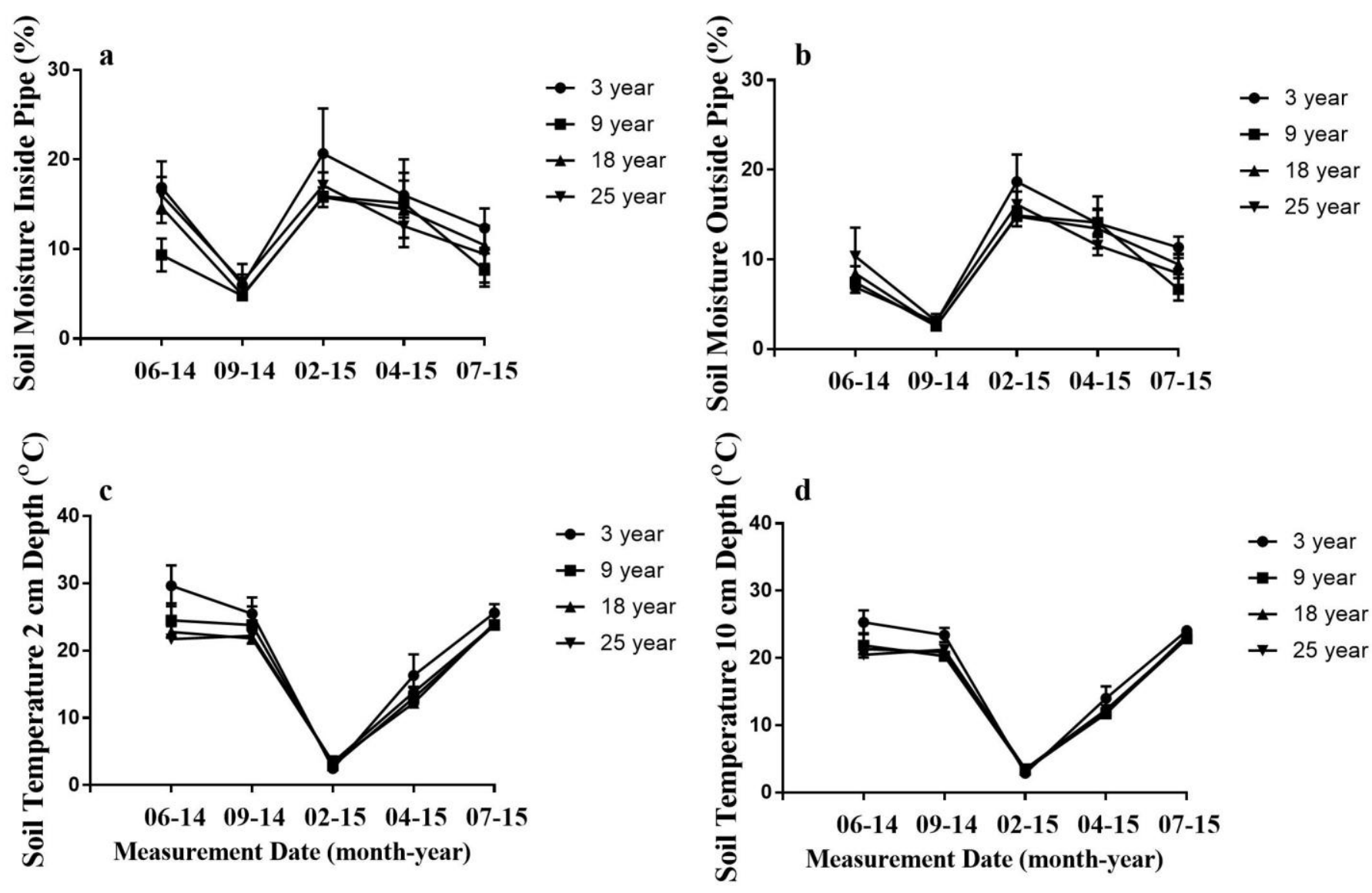

Figure 3: (2-column fitting image) 